\title{
Legal Lore of the Wild West: A Bibliographical Essay
}

\author{
Carleton W. Kenyon*
}

$\mathrm{T}$ HES LEGAL HERITAGE of the English common law, already adapted to American conditions in the Atlantic colonies and Mississippi Valley, further evolved in the distinctive environment of the plains and Pacific coast. The student of this evolution, however, is hampered both by the paucity and fragmentary nature of the available material and by its deplorable presentation. No single publication lias traced the history of law in the West and its administration. What little material is available must be gleaned from such obscure pubhications as bar association proceedings, historical journals, and privately issued biographical sketches and travel books whicll, having appeared in limited editions, soon go out of print. General and local histories have almost totally ignored the judicial aspect of American western history, thus implying that federal and local government operated without courts. Popular books overemphasize the "Wild West," "hemp law," and the heroics of outlaws and rustlers. Certain territories-Arizona, New Mexico, Oklalioma, and Indian Territory-and selected phases of law-mining law, popular justice, and "Judge Colt"-have been given more detailed treatment because the former "enjoyed" a longer period of territorial status and the latter cater to pubhic interest througl exaggerated distortion.

The intent of this essay is to present a selected group of publications, of a secondary and non-official nature, dealing witli the administration of justice in the territorial phase of American government. Geographical coverage is himited to territories of the far west, often designated as the trans-Mississippi region, excluding Cahfornia and Texas. For organizational purposes, the available material is divided into a number of topics. Brief descriptions of the court system, the bench and bar, and the statutory laws are presented with the material relevant to each topic with special focus on prominent features of popular justice, law enforcement, and celebrated cases.

I

\section{ORGANIZED COURTS}

The federal government provided each territory with a supreme court, three district courts, and three judges appointed by the President.

* A.B., 1947, Yankton College; LL.B., 1950, M.A., 1950, University of South Dakota; A.M.L.S., 1951, University of Michigan; Law Librarian, California State Law Library. 
Justices rode circuit separately to hold district courts and met annually as a supreme court "to affirm each other's errors." A general review of the judicial system in relation to the total governmental organization and administration is found in Earl S. Pomeroy, The Territories and the United States, 1861-1890 (Philadelphia: University of Pennsylvania, 1947). A fundamental study of the judicial system as it evolved is that of William W. Blume and Ehzabeth G. Brown, "Territorial Courts and the Law-unifying factors in the Development of American Iegal Institution (pts. 1-2)," 61 Michigan Law Review 39, 467 (1962-1963).

In addition to the jurisdiction granted under federal law, territorial courts exercised jurisdiction over cases arising under the laws of the separate territories. In holding a term of court, judges first tried cases arising under the Federal Constitution and laws, using the remainder of the session to hear cases arising under the laws of the territory.

Procedure in each phase of litigation was usually informal, ("simple, straight-forward justice, unencumbered with nonsense") with emphasis on oral holdings following oral arguments. Few cases were determined by the supreme court because of the great distances to the capital, excessive costs, and the lack of incentive for review when the district judge also appeared on the supreme court bench. Such judicial organization might appear to have the virtues of simplicity, but in reality the administration of justice suffered when each district court was left a law unto itself.

For a number of reasons the federal courts were weak and inefficient if not altogether a failure. As mentioned above, the district courts were virtually autonomous. Furthermore, the Department of Justice, in nominal control of the territorial judicial system, asserted almost no authority over its operation. Lack of supervision from above was combimed with the local citizens' hostility towards federal judges, whom they considered to be carpetbaggers receiving relatively undesirable appointments for political services rendered in the East. Their continuous quarrels with unpopular judges led to forced resignations or "sagebrushing"assignment to a district where judicial busmess was almost nonexistent or where riding circuit was too difficult. Although the judges received salaries too low to cover western hiving costs or to compensate for the distances and other peculiarities of the frontier, they were forbidden to augment their incomes by practicing law.

The administration of justice was neither swift nor of the highest quahty. District courts could not handle their business because of the remote locations of sessions, the vast area which each court served, the difficulties of travel, the lack of funds, and poor communication. Undoubtedly because of the working conditions mentioned above, many judges were unfit and even corrupt-flagrantly so in Nevada during the 
Comstock Lode litigation - and often indulged in political manipulation, being more interested in furthering their private fortunes than in dispensing justice. A number of judges looked upon their assignment in the West as a kind of exile, and their frequent absences from their posts and constant changes in personnel made delays inevitable. The federal treasury was niggardly in bearing court expenses, and court fees were higl. The inadequacy of judicial admimstration led in many instances to local solutions whereby probate, justice, and other local courts increased their jurisdiction at the expense of the federal courts; self-constituted courts sprang up by necessity where courts were not formally organized or functioning.

No general survey has appeared on the practical operation of western territorial courts. The most complete study of a single territorial court is Arie W. Poldervaart, Black-robed Justice; A History of the Administration of Justice in New Mexico from the American Occupation in 1846 until Statehood in 1912 (Santa Fe: New Mexico Historical Soc'y, 1948). An interesting and personal description is by Richard E. Sloan, Memories of an Arizona Judge (Stanford University, 1932). Forbes Parkhill, The Law Goes West (Denver: Sage, 1956), describes the territorial courts in Colorado. A disappointing work, short on legal phases, by a resident of Kansas, Colorado, Wyoming, and Dakota, is Judge William L. Kuykendall, Frontier Days; A True Narrative of Striking Events on the Western Frontier (Denver: 1917).

Other studies, of a more himited and disconnected nature, are the following, histed by territory:

ARIZONA:

F. Lockwood, Pioneer Days in Arizona from the Spanish Occupation to Statehood (New York: Macmillan, 1932).

Kelly, First Term District Court Held in Graham County, ARIz. Hist. Rev., Oct. 1928, at 63.

\section{Colorado:}

Bell, Territorial Day Courts, 11 Dicta 45 (1933).

Stearns, Colorado: A Study in Frontier Sovereignty, 28 L. LIBRARY J. 139 (1935); 8 Rocky MT. L. REv. 233 (1936); 14 Dicta 357 (1937).

Stone, History of the Appellate Courts of Colorado, 8 ANN. Colo. B. Ass'N Proc. 15 (1905) (speech).

IDAHO:

T. Donatdson, Idaero of Yesterday (Caldwell: Caxton, 1941) (personal observations by a lawyer and court clerk). 
Montana:

Brantly, Judicial Department, 4 Hist. Soc'y of Mont. ContribuTIONS 109 (1903).

Pemberton, Montana's Pioneer Courts, 8 HIst. Soc'y of Mont. ConTRIBUTTONS 99 (1917).

Nevada:

Territorial Centennial of Nevada, 1861-1864, NEv. Hist. Soc'y Rev., July-Dec. 1961, at 1.

New Mexico:

Tittmann, By Order of Richard Campbell, 3 N.M. HIst. Rev. 390

(1928) (description of a probate court during early 1850's).

Tittmann, The Last Legal Frontier, 2 N.M. HIsT. REv. 219 (1927).

OKLAHOMA AND INDIAN:

Bierer, Early Day Courts and Lawyers, 23 OkLA. St. B. Ass'N Proc. 193 (1930) (speech).

Foreman, Oklahoma's First Court, 13 Chronicles of OKLA. 457 (1935).

Williams, The Judicial History of Oklahoma, 5 Okra. St. B. Ass'N Proc. 107 (1911).

Williams, The Judicial History of the Supreme Court of the Indian Territory, 27 Medico-LEGAL J. 42 (1909).

OREGON:

Kaplan, Courts, Counselors and Cases: The Judiciary of Oregon's Provisional Government, 62 ORE. HIST. Q. 117 (1961).

UTAH:

Davis, Western Justice: The Court at Fiort Bridger, Utah Territory, 23 UTAH Hist. Q. 99 (1955).

Sutherland, Address of the President, 1 UtaA Territorial B. Ass'N REP. 5 (1894).

WASHINGTON:

J. Swan, The Northwest Coast; Or, 'Three Years' Residence in WASHINGTON TERritoRy (New York: Harper \& Bros., 1857).

Beardsley \& McDonald, The Courts and Early Bar of Washington Territory, 17 WASH. L. REv. 57 (1942). 
II

THE BENCH

Incompetents, buffoons of the Roy Bean type, and alter ego "Judge Colts" who made their own law often graced the frontier bench. However, there were many judges of widely varying character who were both fearless and learned. Outstanding among these were Isaac C. Parker, judge of the United States District Court for Western Arkansas, whose jurisdiction included Indian country; Matthew P. Deady, justice of the Oregon Supreme Court and later judge of the Federal District Court of Oregon, also noted for his code drafting and reporting of decisions; and Kirby Benedict, chief justice of the New Mexico Supreme Court. Judge Parker, known as the "Hanging Judge," in his twenty-one years on the bench tried nore than 13,000 persons, convicting more than 9,000 . Of 344 convicted of crimes that carried the death penalty, he sentenced 172 to be hanged, and 88 swung. Accounts of the careers of these three notable jurists are found in the following:

ISAAC C. PARTEER:

H. Croy, He Hanged Them High; An Authentic Account of the Fanatical Judge Who Hanged Eighty-eight Men (New York: Duell, Sloan \& Pearce, 1952).

S. Harman, Hell on the Border: He HaNged Eighty-eight MeN (Fort Smith: Hell on the Border Pub. Co., 1953) (written by a professional juryman, guided by J. Warren Reed, lawyer and nemesis to Parker).

F. Harrington, Hanging Judge (Caldwell: Caxton, 1950).

G. SHIRIEY, LAW West of Fort SMith: A History of Frontier JUSTICE IN THE INDIAN TERRITORY, 1834-1896 (New York: Holt, 1957).

Daily, Judge Isaac C. Parker, 11 Chronicles of OKLA. 673 (1933).

Semple, Isaac C. Parker, Judge of the United States Court, $22 \mathrm{~J}$. OKIA. B. Ass'n 1257 (1951).

Matthew P. Deady:

Platt, Matthere P. Deady, 1824-93, in 7 W. LewIS, Great AmERICAN LAWYERS 357 (Philadelphia: Winston, 1909).

Sears, Matthew P. Deady: A Sketch, 1904 Ore. B. Ass'N Proc. 230 (10th-13th Annual Meetings).

Teiser, A Pioneer Judge of Oregon-Matthew P. Deady, 44 ORE. Hrst. Q. 61 (1943). 


\section{KIRBY BENEDICT:}

A. Hunt, KIRBy BeNEdict, Frontier Judge (Glendale: A. H. Clark Co., 1961).

Twitchell, Kirby Benedict, 1 Odd Santa Fe 50 (1913).

Judges were important in the administration of western law even though individual judges were often seriously inadequate. Although most of the cases confronting them involved prosaic issues, territorial development presented them with new questions of law, especially in the areas of mining, water, and public lands, where no federal statutes or legal precedents were available.

Judicial duty, for the most part, consisted of riding circuit over wide jurisdictional areas and holding trial court sessions in remote places. A retinue of court officials, lawyers, interpreters, and prisoners accompanied a judge on circuit. Circuit riding was the occasion for gala affairs and interesting episodes, with picturesque attendants sharing meager accommodations under primitive travel conditions. The best description of a six months circuit trip, covering 2,000 miles, is given by William W. $\mathrm{H}$. Davis, a United States Attorney for New Mexico during the 1850's, in his travel book El Gringo, Or, New Mexico and Her People (Chicago: Rio Grande, 1962).

Court days or court week competed with fairs, circuses and other social affairs for local interest. Court sessions were held in saloons, school houses, stores, and other available buildings, under the shade of trees or tents, in open streets, or on the prairie. When court houses were constructed, they were usually frame structures providing rude accommodations, with sawdust floors, deal tables, and cheap wooden seats; they often doubled as morgues, polling places, and jails, and furnished opportunities for social gatherings. Their temporary nature is vividly illustrated by an incident at a murder trial held in a Colorado theater. The judge was informed that the joists of the building were giving way along one wall and the main floor was sinking. The defense counsel, absorbed in his speech to the jury, was called to attention by the judge's gavel and told to take his seat. He objected and resisted interruption, but the judge again brought down his gavel and yelled out in his highest falsetto key: "I tell you to sit down; this is not a question of politeness between you and me; the question is whether this whole shebang is going to hell or not." The episode is related in Wilbur F. Stone, "Pioneer Bench and Bar of Colorado," 11 Annual Colorado Bar Association Proceedings 101, 111 (1908) (speech).

Extreme casualness, untrammeled by the usual conventionalities, pre- 
vailed in courtroom behavior. Judges rested their feet on a desk, chewed a quid and whittled, while the lawyers smoked and spat tobacco. Motions put by dry spectators, to adjourn for a wet refresher, always carried. In Oklahoma, the official crier at the federal court used to open the proceedings by shouting, "Hear ye! Hear ye! Now all you mully-grubs in the back of the courtroom keep your traps shut and give these swell guys up in front a chance to talk!"

Court procedure was rough and ready, and court was often conducted in a summary and arbitrary fashion. In one territory, for example, the sheriff impanelled a jury by selecting in sequence squint-eyed, fat, tall, and thin men. Not surprisingly, decisions of judge and verdicts of juries were at times irregular and unique. A judge in Idaho called the court calendar arbitrarily, overruling and sustaining demurrers alternately throughout his hist. A druggist presiding over an Arizona court was considered "sui generis, a composite of severity, humor, nonsense, and some law." His library consisted of Materia Medica and "Somebody" on Fractural Bones. His process was summary, a chain gang of guilty offenders was established to clean up the streets, and lawyers were refused recoguition to appear. One lawyer, appearing for a client, demurred to his client's court sentence on the ground of prejudice and demanded a jury trial. The judge in turn sentenced the lawyer as well to the clrain gang saying, "Now, how you like dat trial by shury?" The judge is described in Frank C. Lockwood, Pioneer Days in Arizona from the Spanish Occupation to Statehood 263-64 (New York: Macmillan, 1932). The invariable rule of the court in civil cases was that the wealthier party always paid costs, whatever the decision. Because cash on the frontier was scarce, goods of one kind or another were accepted as fines. One prisoner, found guilty of contempt, was charged a blanket for the judge and a pair of breeches for the United States marshall.

The irregularity of justice was increased by community disrespect for the processes of law. Althougl judges and prosecuting attorneys might be zealous, juries were easily influenced by friends or intimidated by foes. Juries were therefore lenient, dispensing justice with mercy to such an extent as to discourage many United States attorneys from seeking convictions. Juries were not the only target of community pressure, however, and many a frontier judge found it wise to arm himself in court. A Wyoming judge was threatened by gambler friends of a dance-hall bouncer he had sentenced to jail. "Look here, Clay, you've got to suspend that jail sentence," said one. "There's going to be trouble if you don't." The judge without answering, walked back to the bench and took out a pistol containing a double charge of powder and shot. "The gun," he 
said, "will always be here to make that sentence good." Robert B. David relates the story in Malcolm Campbell, Sheriff 132 (Casper: Wyomingana, 1932).

Despite the irregularity and informality of the courts, however, procedure was not simple. Complications arose from questions of the correct forum and of novel substantive law; further problems involved the bribery of judges, juries, and witnesses, and courtrooms filled with armed spectators. In dealing with such problems, however, citations to authoritative sources of law were infrequently made; instead, impassioned eloquence and strong rhetoric flourished.

The following biographical accounts portray the condition of the judiciary in generally laudable terms:

Colorado:

Holland, Benjamin Franklin Hall, First Chief Justice, Territory of Colorado, 9 Dicta 48 (1931).

Holland, Early Colorado Courts and Judges, 9 Dicta 22 (1931).

Holland, Stephen Selwyn Harding, Chief Justice, Territory of Colorado, 1863-1865, 9 DICTA 113 (1932).

South Dakota:

Grantham, The Black Hills Judiciary, 25 S.D.B. Ass'N ReP. 174 (1924).

IDAHO:

Bell, Judicial History of Idaho, 6 LAWYER \& BANKER 278 (1913).

Montana:

J. Lindsay, Amazing Experiences of a Judge (Philadelphia: Dorrance, 1939).

New MeXico:

Watson, Frank Wilson Parker, 7 N.M. HIst. Rev. 377 (1932).

Watson, The Extra Legal Interest of Early Nere Mexico Decisions, 1942 N.M.B. Ass'N Minutes 32.

OKLAHOMA AND INDIAN:

Meserve, From Parker to Poe, Being a Brief Sketch of the Early Judiciary of Tulsa County, 16 ChronICLes of OKLA. 89 (1938).

OREGON:

Boise, Fifty Years' Recollection of the Bench and Bar of Oregon, 1904 Ore. B. Ass'n Proc. 256 (10th-13th Annual Meetings). 
Knickerbocker Views of the Oregon Country: Judge William Strong's Narrative, 62 ORE. HIST. Q. 57 (1961).

Teiser, First Associate Justice of Oregon Territory, O. C. Pratt, 49 ORE. HiST. Q. 171 (1948).

Teiser, Life of George H. Williams: Almost Chief Justice (pts. 1-2), 47 ORE. HIST. Q. 255, 417 (1946).

Teiser, The First Chief Justice of Oregon Territory: William $P$. Bryant, 48 ORE. HIST. Q. 45 (1947).

Teiser, The Second Chief Justice of Oregon Territory: Thomas Nelson, 48 ORE. HIST. Q. 214 (1947).

Teiser, William Strong, Associate Justice of the Territorial Courts, 64 ORE. HIST, Q. 293 (1963).

WASHINGTON:

C. Reinhart, History of the Supreme Court of the Territory and State of Washington (1931).

Babb, Judge E. P. Oliphant, 11 WASH. Hist. Q. 254 (1920).

Johnson, George Turner, A Character from Plutarch (pt. 1), 18 WASH. L. Rev. 167 (1943); id. (pt. 2), 19 WASH. L. Rev. 18 (1944).

WYOMING:

Potter, Sidelights on the Wyoming Judiciary, 8 WYo. St. B. Ass'N Proc. 60 (1921).

III

THE BAR

Unfortunately territorial lawyers were as reticent as modern day lawyers in preserving their experiences in print. Personal reminiscences have occasionally appeared in hittle-known bar association proceedings but only after the relator has outlived his brethren. These first hand accounts do little more than praise the renown and accomplishments of fellow lawyers and judges or recount whimsical episodes and humorous anecdotes. Biographies are mere formal descriptions. In neither case is much attention paid to the practitioner's daily work. Thus, it is difficult to acquire a conprehensive picture of the western lawyer's practice. The most general description is found in Everett Dick, "Lawyers and Legal Proceedings," in his The Sod-house Frontier, 1854-1890: A Social History of the Northern Plains from the Creation of Kansas \& Nebraska to the Admission of the Dakotas (New York: Appleton-Century, 1937).

Lawyers formed one of the largest groups of professional men in the territories. Few qualifications were necessary for admission to the bar. 
Early years were lean ones for lawyers and most of them were not very successful in their legal practice. To support themselves, they resorted to working in mines, newspapers, business, surveying, and other occupations. Mining areas, which initially refused to permit lawyers to practice, seemed to attract many of the least successful eastern practitioners. Early cases were usually petty ones; all the important litigation involved only a few persons. The first lucrative cases were those dealing with land claims and titles tried before the United States Land Office, with appeal to the Commissioner in Washington, and those involving mining claims and claim jumping. Lawyers also profitably handled mortgages and the collection of debts and acted as loan brokers. Territorial lawyers were necessarily versatile, persevering, and resourceful. They worked hard, riding circuit with judges and their traveling courts over immense areas at their own expense. Many of the lawyers accompanying the court party had cases, but others went along hoping to obtain fees as assistants to local attorneys. Some traveled with their own conveyances and either stopped at hotels or cabins or had their own camping outfits.

In conducting trial work, lawyers depended almost exclusively on forceful, vigorous oratory and personal magnetism and wit to win favorable jury verdicts. The judge was regarded as "a useless appendage in the halls of justice," as is illustrated by the following story of uncertain tradition: An Idaho judge, instructing the jury, charged them to find for the defendant if they believed his counsel, or to find for the plaintiff if his counsel was more convincing, "but if you are like me and don't believe a damned word that either of them says, I don't know what in hell you will do." Appeal work was an infrequent practice.

The purchase of a large library was unnecessary since libraries were practically unknown. Available books included a few reports, texts, and a copy of the laws. Generally the lawyer carried his library in his hat and his office on the back of a mule. In Oklahoma, it was said that "at first we practised without books, forms, or legal precedents, with Winchester rifles sometimes as our rules of court." One Oregon lawyer who owned a copy of Bacon's New Abridgement of the Laze (London: A. Strahan, 1798) cited it in presenting his case. His opponent asked to see the work and when his turn for argument came he addressed the judge by showing surprise at the use of the book in an American court: "This is English, not American law. This book, as it is plainly written here on the title page, was written in London, England, in the Inner Temple. It is the law of England, of the people who oppressed our fathers, and the law which they repudiated in the Declaration of Independence. [My opponent] is trying to inipose on the court." The judge ruled the law in Bacon out of court. The episode is found in Reuben P. Boise, "Tifty Years' Recollection of 
the Bench and Bar of Oregon," 1904 Oregon Bar Association Proceedings 256, 260 (10th-13th Annual Meetings).

One of the most unusual members of the territorial bar was William H. Clagett. Clagett, entering Nevada as a "gold-rush" lawyer, is described by a former friend as one of the party of four prospectors in Mark Twain's Roughing It (New York: Harper \& Row, 1871). (Twain's work is a western classic, narrating episodes of mining cases, road agents, and vigilante actions.) Claggett continued to practice through the mining rushes of Colorado, Montana, Dakota, Idaho, Oregon, and Washington, and is described by W. W. Dixon, "Sketch of the Life and Character of William Claggett," 4 Historical Society of Montana Contributions 249 (1903).

Another colorful and prominent pioneer Idaho lawyer, James $\mathrm{H}$. Hawley, is indifferently presented by a latter-day lawyer and judge, John F. MacLane, A Sagebrush Lawyer (New York: Pandick Press, 1954).

The legal fraternity located in the Coinstock Lode region became the leading beneficiaries of that bonanza. The cost of litigation over the principal mines of Nevada was estimated to be around ten million dollars. One leading lawyer, William M. Stewart, who drew up the first quartz mining rules and regulations in Califorma, used them in the Comstock Lode litigation (making a fee of 300,000 dollars in four years), and as United States Senator from Nevada incorporated them into federal law. His life is found in his Reminiscences of Senator William $M$. Stewart, of Nevada (New York: Neale, 1908), and in Effie M. Mack, "William Morris Stewart, 1827-1909," Nevada Historical Quarterly, Jan.-June 1964, at 1.

Personal reminiscences and biographical accounts are available in the following works:

ARIZONA:

Baker, Early Arizona Court Experiences, ARIz. HIST. Rev., Oct. 1929, at 73.

Colorado:

Rogers, Reminiscences of Bench and Bar, 30 CoLO. B. Ass'N REP. 130 (1927) (speech).

Stanton, Reminiscences of the Bench and Bar of Colorado in Early Days, 16 Coro. B. Ass'N Rep. 205 (1913) (speech).

Stone, Pioneer Bench and Bar of Colorado, 11 Colo. B. Ass'N REP. 101 (1908) (speech).

Thomas, The Pioneer Bar of Colorado, 1 Colo. Magazine 193 (1924). 
Wikoff \& Teetor, The Bench and Bar of Denver and Colorado (pts. 1-2), 9 MAGAZINE OF W. HIst. 605, 764; id. (pts. 3-5), 10 MAGAZINE OF W. HIST. 56, 163, 312 (1889).

SOUTh DaKota:

Bailey, Address, 25 S.D.B. Ass'N Rep. 112 (1924) (speech).

Clark, The Lamp of Experience, 25 S.D.B. Ass'N REP. 185 (1924).

Crawford, The Bench and Bar in Early Territorial Days, 25th S.D.B. Ass'N ReP. 140 (1924).

Rice, Territorial Days-and Some Desirable Changes in Our Practice, 25 S.D.B. Ass'N REP. 158 (1924).

IDAFO:

Sullivan, The Bench and Bar of Idaho as I Have Known Them, 3 IDAHO ST. B. REP. 146 (1927) (address by an Idaho Supreme Court Justice).

KANSAS:

Ingalls, Some Ingalls Letters, 14 KaN. St. HIst. Soc'y Coldectrons 94 (1918).

NEBRASKR:

O. AbBott, Recollections of a Pionecr Lawyer (Lincoln: Nebraska State Historical Society, 1929).

Savage, The Bar of Omaha, 9 MAGAzINE of W. HIst. 201, 277 (1888).

NEVADA:

History of the Bench and Bar of Nevada (J. O'Brien ed. San Francisco: Bench and Bar, 1913).

New Mexico:

O. Wilitams, Pioneer Surveyor-Fronter Lawyer: The PerSonal NarRative of O. W. WIIIIAMs, 1877-1902 (El Paso: Texas Western College Press, 1966).

Clancy, Reminiscences of Territorial Days, 33 N.M.B. Ass'N MrNUTES 47 (1919).

OKLAHOMA:

Turner, Prairie Dog Lawyers, 2 Panhander Plains Hist. Rev. 104 (1929). 
OREGON:

History of the Bench ANd Bar of OREgon (Portland: Historical, 1910).

McBridge, Reminiscences of the Oregon Bar, 2 ORE. L. ReV. 135 (1923).

Pratt, ed., 22 Letters of David Logan, Pioneer Oregon Lawyer, 44 ORE. Hist. Q. 253 (1943).

\section{UTAF:}

R. BAskin, Reminiscences of EarLy UtaH (Salt Lake City: Tribune-Reporter Printing Co., 1914) (litigation involving Mormons by former chief justice of the Utah Supreme Court).

Booth, The Early Bench and Bar, 15 UTAH ST. B. Ass'N REP. 72 (1913) (address).

WASHINGTON:

Caton, Pioneer Judges and Lawyers, 8 WASH. St. B. Ass'N Proc. 63 (1896).

Caton, Some Pioneer Judges and Lawyers I Have Known, 15 WASH. St. B. Ass'N Proc. 75 (1903).

Hanford, Members of the Seattle Bar Who Died Young (pt. 1), 16 WasH. Hrst. Q. 122 (1925); id. (pt. 2), 17 WASH. Hrst. Q. 18 (1926).

Hoyt, Reminiscences of the Bench and Bar of Washington, 9 WASH. ST. B. Ass'N Proc. 155 (1897).

Jacobs, Reminiscences of the Bench and Bar of Washington, 6 WASH. ST. B. Ass'N Proc. 132 (1894).

McGilvra, The Pioneer Judges and Lawyers of Washington, 7 WASH. St. B. Ass'N Proc. 90 (1895).

WYOMING:

Brown, Early Reminiscences of the Bar, 5 Wyo. St. B. Ass'N PRoc. 58 (1919).

Campbell, Fading Memories, 15 Annals of Wyo. 38 (1943).

$$
\begin{gathered}
\text { IV } \\
\text { LAWS }
\end{gathered}
$$

Statutory law in the territories was often uncertain and confused. Sometimes newly created territories had no enacted law between the adoption of an organic act and the first meeting of the legislature; even then legislatures often acted irresponsibly by passing new laws which 
created "perplexing discrepancies." The practice of haphazardly copying the statutes of other jurisdictions, without adapting them to local conditions, resulted in anomalous, hodge-podge legislation. Subsequent clarification became necessary and was achieved through codification or revision under the supervision of a person of the caliber of David Dudley Field.

Once enacted, legislation was not always readily available because of the lack of printing and binding facilities in the territory. Publication required printing at eastern presses, with the hazards of delay and return shipinent; territories consequently had no published laws. Early officials were notoriously careless about written records and early court reports were seldom pubhished. It took twenty years before the first volume of the Idaho supreme court decisions was issued.

The most notorious example of the uncertain condition of statutory enactment was the Lilliputian controversy in Oregon over whether the legislature had adopted the Iowa Revised Statutes of 1843 ("Big Blue Book") or the Iowa Acts of 1839 ("Little Blue Book"). This battle is described in the following:

Beardsley, Code Making in Early Oregon, 27 Pac. NoRThwest Q. 3 (1936); 23 ORE. L. REV. 22 (1943).

Herriott, Transplanting Iowa's Laws to Oregon, 5 ORE. HIST. Q. 139 (1904).

Kelly, History of the Preparation of the First Code of Oregon, 4 ORE. Hist. Q. 185 (1903).

Warner \& Harris, History of the Oregon Code (pts. 1-2), 1 ORE. L. Rev. 129, 185 (1922).

In Arizona, a supreme court judge decided the acts of the first two territorial legislatures were illegal and the laws of no force, leaving the territory virtually without either a government or a legal framework. A newly appointed governor resolved the chaos by having Congress pass bills legalizing all acts of the legislature. The incident is described in John Spring's Arizona 194-95 (A. Gustafson ed. Tucson: University of Arizona, 1966).

\section{$\mathrm{v}$ \\ POPULAR JUSTICE}

The territorial west was not only a turbulent area but often a lawless one, attracting rough and law-defying persons from more settled regions. Although most people were law-abiding, the loosely assembled civil authority and the few courts, judges, and peace officers had insufficient control to safeguard life and property; law enforcement therefore lagged 
behind violation of the law. To deal with claim jumpers, horse thieves, cattle rustlers, train and stagecoach robbers, and unpunished killers, local residents were forced to use direct and prompt methods of preserving "law and order." They resorted to local rules and regulations, popular courts, the revolver, and "Judge Lynch." For example, when crime became too frequent during 1864 in Aurora, Nevada, a group called the "Protective Union" rounded up all badmen and unconvicted criminals, banished many from the town, and, with the help of the local militia, sent four to the gallows.

Another example of spontaneous lynching occurred in Tucson, Arizona, in the 1870's following the murder of a pawnbroker and his wife. An impromptu public safety committee tracked down the three murderers and administered "swift and sure" justice by verdict of the committee. The citizens' committee spokesman stated:

You have been proved guilty of this crime, and you must all prepare to die tomorrow. You need not hope to escape through legal trickery or court delay; there will be no further trial. The people of Tucson have found you guilty, and the citizens themselves will hang you.

The three condemned murderers were promptly executed along with a convicted murderer from the local jail. This episode is told in Frank C. Lockwood, Pioneer Days in Arizona from the Spanish Occupation to Statehood 270 (New York: Macmillan, 1932) and John G. Bourke, "A Lynching at Tucson in 1873," (pts. 1-2), 19 New Mexico Historical Review 233, 312 (1944). A good description of early frontier law in Idaho is William J. McConnell, Frontier Law: A Story of Vigilante Days (New York: World, 1926). The popular and provisional tribunals associated with frontier law were abandoned after regularly established courts and officers becanie effective, and some of the customs followed were incorporated into formal law. Two accounts of the "law and order" variety -describing the popular administration of justice-are provided by Wayne Gard, Frontier Justice (Norman: University of Oklahoma Press, 1949) and Carl C. Rister, "Frontier Justice," Chapter 15 of his Southern Plainsmen 189 (Norman: University of Oklahoma Press, 1938). A regional study was made by Henry A. Dubbs, "The Unfolding of Law in the Mountain Region," 3 Colorado Magazine 113 (1926). In order to deal with law violators in an organized way, agricultural communities established claim clubs; ranchers organized Regulators and Anti-Horse Thief Associations and Cattle Associations; and larger nonmining settlements created "people's courts." The most publicized temporary community efforts involved the Vigilantes-secret committees in mining and other areas-whose activities have been extensively documented: 
N. Langford, Vigilante Days and Ways: The Pioneers of the Rockies, the Makers and Making of Montana, Idaho, OregoN, Washington and Wyoming (Missoula: Montana State University Press, 1957).

J. Miller, Arizona, The Last Frontier (New York: Hastings, 1956).

Botkin, Justice Was Swift and Sure in Early Kansas, 16 KaN. Hist. CoLlections 488 (1925).

Nebeker, Early Justice in Utah, 3 UTAF HisT. Q. 87 (1934).

Rister, Outlaws and Vigilantes of the Southern Plains, 1865-1885, 19 Miss. Valley Hist. Rev. 537 (1933).

Williams, Trials and Judgments of the People's Courts of Denver, 27 Colo. Magazine 294 (1950).

Vigilantes made some mistakes, recalls an old-timer, but they were effective, often easing the work of law enforcement officials and furthering the effective administration of the judicial system. The Montana committees, for example, did noteworthy work in exposing and hanging both Sheriff Henry Plummer and his gang of desperadoes and the noted thief Joseph A. Slade, former division head of the Overland Stage Company. Accounts can be found in:

H. Birney, Vigilantes: A Chronicle of the Rise and Fali of the Plumamer Gang of Outlaws in and about Virginia City, Montana, in the Early 60's (Philadelphia: Pennsylvania Pubhishing Co., 1929).

T. Dimsdale, The Vigilantes of Montana, or, Popular Justice IN THE Rocky MountaINs (Nornnan: University of Oklahoma Press, 1956):

The Banditti of the Rocky Mountains and Vigrlance ComMITTEE IN IDAHo (Minneapolis: Ross \& Haines, 1964).

$X$. Beidier: Vigilante (H. Sanders ed. Norman: University of Oklahoma Press, 1957).

Miners, in urgent need of the protection of law, banded together by districts and drew up rules and regulations for filing claims and trying cases in miners' courts, either before a judge, jury, or board of arbitrators. Lawyers were usually forbidden to appear. No technicalities were allowed to defeat the ends of justice; execution of judgment was speedy and without appeal; and sentences might consist of flogging, banishment, or hanging. An illustrative case can be found in the early annals of the Rogue River Valley in Oregon. The local alcalde decided a disputed claim involving two mining partners contrary to public sympathy. The miners 
proceeded to set up a court of appeal based on a writ of "sympathy and sense of justice," appointed a chief justice, summoned a jury, retried the case, and rendered a judgment reversing the alcalde's decision. The story is told in The Mining Frontier: Contemporary Accounts from the American West in the Nineteenth Century 10-18 (M. Lewis ed. Norman: University of Oklahoma Press, 1967); A. Richardson, Beyond the Mississippi: From the Great River to the Great Ocean 407-08 (Hartford: American Publishing Co., 1867). The general operation of these courts is shown in the following:

R. Hughes, Pioneer Days in the Biack Hitis (Glendale: Clark, 1957).

E. Lord, The Drama of Virginia City (Reno: Nevada State Journal, 1926).

E. LoRd, Comstock Mining and Miners (Berkeley: Howell-North, 1959).

G. Iyman, The Saga of the Comstock Lode: Boom Days in VIRGINIA CITY (New York: Scribner, 1934).

Marshall, The Miners' Laws of Colorado, 25 Am. Hist. Rev. 426 (1920).

Perrigo, Law and Order in Early Colorado Mining Camps, 28 Miss. VALIEX Hist. Rev. 41 (1941).

Rogers, The Mining District Governments of the West: Their Interest and Literature, 28 L. LIBRARY J. 247 (1935).

Rogers, The Beginnings of Law in Colorado, 36 DICTA 111 (1959).

VI

\section{LAW ENFORCEMENT}

Enactment of laws and organization of courts were only the first steps in establishing order in the territories. The subsequent and crucial step was enforcement of law through peace officers, particularly federal marshals, local sheriffs, and their deputies. Their job was a difficult and exceedingly risky one- of the 200 marshals and deputies serving in Indian Territory between 1875 and 1895, sixty-five were killed in the line of duty. Apprehending criminals was difficult because of inadequate conlmunication and investigation devices and reliance on individual action. Confinement of prisoners in "leaky" jails was equally difficult. The plains, with hittle timber and stone, presented a problem in housing prisoners. Often culprits were chained to a tree or a telephone pole, or placed in a dry cistern.

Peace officers were a varied group. Some, like Wyatt Earp, Elfego Baca, and Henry Pluminer, acted simultaneously as lawmen and outlaws; 
others, such as Bat Masterson and "Wild Bill" Hickock, were gunmen operating occasionally as lawmen. General stories of this unheralded group of courageous and aggressive men can be found in:

C. Breitan, Great Lawnen of the West (London: Long, 1963).

C. McKennon, Iron Men: A Saga of the Deputy Untted States Marshals Who Rode the Indian Territory (Garden City: Doubleday, 1967).

W. Ratne, Guns of the Frontier: The Story of How Law Came To THE WeSt (Boston: Houghton Mifflin, 1940).

W. Raine, Famous Sheriffs and Western Outlaws (Garden City: Doubleday, Doran, 1929).

E. SABIN, WIId MEN of the WIID West (New York: Crowell, 1929).

The "Three Guardsmen"-Ben Tilghman, Chris Madsen, and Heck Thomas-became known for their prowess as federal marshals. Their experiences are described in:

Z. Thlmman, Marshal of the Last Frontier: Life and Services of William Matthew (BIII) TIlghman, For 50 Years ONE of the Greatest Peace Officers of the West (Glendale: Clark, 1949).

H. Cory, Trigger Marshal: The Story of Chris Madsen (New York: Duell, Sloan \& Pearce, 1958).

G. Shirlex, Heck Thomas, Frontier MarshaI: The Story of a Reai Gunfighter (Philadelphia: Chilton, 1962).

Other noted peace officers, whose drive for adventure took them to several territories, include the following:

WILITAM M. BREAKENRIDGE:

W. Breakenridge, Helidorado, Bringing the LaW to the MesQUTTE (Boston: Houghton Mifflin, 1928).

Matcolm Campbeli:

R. David, Malcolm Campbeil, Sheriff: The Reminiscences of the Greatest Frontier Shertif in the History of the Platte Valley, and the famous Johnson County Invasion of 1892 (Casper: Wyomingana, 1932).

Frant M. Canton:

F. Canton, Frontrer Trairs (Norman: University of Oklahoma Press, 1966) (autobiography). 
DAvid J. Cook:

W. Collier \& E. Westrate, Dave Cook of the Rockies, Frontter General, Fighting Sheriff, ANd Leader of Men (New York: Wilson, 1936).

D. Coor, Hands Up; OR, Twenty Years of Detective Ltfe in the Mountatns and on the Platns (Norman: University of Oklahoma Press, 1958).

\section{VII \\ NOTED CASES}

The influx of many newcomers into relatively unoccupied territories inevitably resulted in conflicts although few individual cases became cause célèbres. Probably Mark Twain's spurious "Great Landshide Case" in Roughing $I t$ is as well known as any other.

Indian hostilities in Washington Territory led the Governor to declare martial law, after which a civil hiberties dispute ensued between the executive and the judiciary. This is narrated in Samuel F. Cohn, "Martial Law in Washington Territory," 27 Pacific Northwest Quarterly 195 (1936), and Roy N. Lokken, "The Martial Law Controversy in Washington Territory, 1856," 43 Pacific Northwest Quarterly 91 (1952).

The struggle between land owners and homesteaders involved bitter litigation and occasionally broke out into armed assault. Titles to Spanish and Mexican land grants (especially the Maxwell Land Grant, the largest land holding in the United States) and conflicting land claims led to the Lincoln County and Colfax County wars in New Mexico. Descriptive accounts of the controversies between land occupiers and incoming settlers include:

A. Cleaveland, Satan's Paradise: From Lucien Maxwell to Fred LAMBERT (Boston: Houghton Mifflin, 1952).

G. Coe, Frontier Fighter: The Autobiography of George W. Coe, Who Fought and Rode with BILly the Km, As ReLated to NaN Hilladry Harrison (Boston: Houghton Mifflin, 1934).

G. Curry, George Curry, 1861-1947, AN Autobiography (Albuquerque: University of New Mexico Press, 1958).

W. Keleher, Violence in Lincoln County, 1869-1881 (Albuquerque: University of New Mexico Press, 1957).

W. Keleher, Maxwell Land Grant: A New Mexico Item (New York: Argosy-Antiquarian, 1964).

J. Pearson, The Maxwell Land Grant (Norman: University of Oklahonia Press, 1961). 
The most fascinating land title case grew out of the Peralta Grant claim made by the "Baron of Arizona," John Reavis, to 12.5 million acres of Arizona and New Mexico, including the Salt and Gila River valleys and Phoenix. Reavis, with the backing of lawyers Senator Roscoe Conkling and Robert G. Ingersoll and Collis P. Huntington and the Southern Pacific, operated a protection racket on the basis of the claim during the 1880's and early 1890's. Finally, in 1895, the fictitious nature of the grant was established during the trial before the Court of Private Land Claims in Santa Fe, and the "Baron" was subsequently arrested and tried for fraud before a federal court. The fantastic account of Reavis and his trials is found in Edward Spiro, The Baron of Arizona (New York: Day, 1967), and Donald M. Powell, The Peralta Grant: James Addison Reavis and the Barony of Arizona (Norman: University of Oklahoma Press, 1960).

Disputes between cattlemen and homesteaders along the Platte River in Nebraska are related in Richard Crabb, Empire on the Platte (Cleveland: World, 1967). The celebrated range war in Johnson County, Wyoming, between cattlemen and newcomers, and the subsequent trials, is chronicled in Asa S. Mercer, The Banditti of the Plains, Or the Cattlemen's Invasion of Wyoming in 1892 (Norman: University of Oklahoma Press, 1954) and Helena H. Smith, The War on Powder River (New York: McGraw-Hill, 1966).

One of the most colorful trials that occurred during the period of rivalry between cattlemen and sheepherders arose out of the Pleasant Valley War in Arizona, otherwise known as the Grahaun-Tewksbury Feud. The feud lasted from 1887 to 1892 , at which time only one adult male survived in each family. Ed Tewksbury then shot Tom Graham from ambush and was brought to trial in dramatic circumstances, whicls included Grahani's widow pulling a gun which failed to fire on the defendant. After several trials and maneuverings for four years, the charge was dismissed. See Earle R. Forrest, Arizona's Dark and Bloody Ground (rev. ed. Caldwell, Idaho: Caxton, 1950).

The leitmotiv of western territorial justice was the attempt to establish and follow the institutions and the tradition of judicial administration prevalent in more settled areas of the eastern United States. With no major work available to trace this development, this bibliographical essay has attempted to set out some of the more popular works which show the effort in its various phases. Beginning with the transient necessity for popular control and primitive judicial organs, through informal court procedure and lagging law enforcement, the final organization of effective, orthodox legal organs was eventually completed with statehood. 